\title{
Molecular detection and clinical aspects of porcine circovirus 3 infection in pigs from Brazil
}

\author{
[Detecção molecular e aspectos clínicos da infecção por circovírus suíno 3 \\ em suínos do Brasil] \\ A.C.M. Cruz ${ }^{1}$, I.L.F. Rodrigues ${ }^{1}$, A.E. Souza ${ }^{1}$, F.B. Knackfuss ${ }^{2}$, \\ R.L. Silveira ${ }^{1}$, T.X. Castro ${ }^{1}$ \\ ${ }^{1}$ Instituto Biomédico - Universidade Federal Fluminense - Niterói, RJ \\ ${ }^{2}$ Escola de Ciências da Saúde, Medicina Veterinária - Universidade do Grande Rio - Duque de Caxias, RJ
}

\begin{abstract}
Porcine circovirus 3 (PCV-3) DNA has been detected in serum samples from apparently healthy pigs as well as pigs with different clinical conditions. Molecular detection of PCV-3 was observed in swine serum samples from Southeastern - Brazil using a nested PCR designed specifically for this study. The epidemiology and clinical aspects of PCV-3 infection were evaluated. The samples originated from 154 pigs of both genders from different production phases and with different clinical presentations, sampled from 31 pig farms visited between 2013 and 2018. In this study, PCV-3 was detected in $26.7 \%$ of samples from all populations across varying ages. Statistical association $(\mathrm{P}=0.0285)$ was observed only between animals with respiratory signs and PCV-3; no PCV-3-positive animal had diarrhea. No statistical association was observed between PCV-3 and age, or gender of the pigs. Because PCV-3 is a newly discovered virus, there is very little information about its epidemiology. We hope that these data can help in future studies investigating PCV-3 epidemiology.
\end{abstract}

Keywords: porcine circovirus, serum sample, nested PCR, swine

\section{RESUMO}

O DNA do circovírus suíno 3 (PCV-3) foi detectado em amostras de soro de suínos aparentemente saudáveis, bem como em suínos com diferentes condições clínicas. A detecção molecular do PCV-3 foi observada em amostras de soro de suínos da região Sudeste do Brasil, com uma nested PCR desenhada especificamente para este estudo. A epidemiologia e os aspectos clínicos da infecção por PCV-3 foram avaliados. As amostras foram coletadas de 154 suínos de ambos os sexos, de diferentes fases de produção e com diferentes sinais clínicos. Os animais pertenciam a 31 granjas visitadas entre 2013 e 2018. Neste estudo, o PCV-3 foi detectado em $26,7 \%$ das amostras de animais saudáveis e de animais com variados sinais clínicos, de ambos os sexos e de idades variadas. Associação estatística $(P=0,0285)$ foi observada apenas entre animais com sinais respiratórios e PCV-3; nenhum animal positivo para PCV-3 apresentava diarreia. Não foi observada associação estatística entre o PCV-3 e a idade ou o sexo dos suínos. Por se tratar de um vírus recém-descoberto, existem poucas informações sobre sua epidemiologia. Espera-se que os dados deste trabalho possam contribuir para futuros estudos sobre a epidemiologia do PCV-3.

Palavras-chave: circovírus suíno, amostra de soro, nested PCR, suíno

\section{INTRODUCTION}

Porcine circovirus 3 (PCV-3) is a virus belonging to the Circoviridae family and since 2015 (Palinski et al., 2016; Phan et al., 2016)

Recebido em 28 de fevereiro de 2020

Aceito em 29 de junho de 2020

E-mail: menezescruz@gmail.com represents the third member of the family with the ability to infect swine, together with the nonpathogenic porcine circovirus $1(\mathrm{PCV}-1)$, and pathogenic porcine circovirus $2(\mathrm{PCV}-2)$. $\mathrm{PCV}-2$ is one of the most economically relevant viruses for the swine industry worldwide (Yao et al., 2019). PCV-3 was detected in swine from all 
ages and was associated with different clinical conditions (respiratory, reproductive, gastrointestinal, multi-systemic inflammation, and neurological disorders) (Palinski et al., 2016; Phan et al., 2016; Zhai et al., 2017; Kedkovid et al., 2018; Chen et al., 2019) and also in apparently healthy animals (Zheng et al., 2017; Guo et al., 2019).

The diagnosis of PCV-3 is currently based on DNA detection in different clinical samples including serum, tissue, colostrum, and feces (Franzo et al., 2017; Fu et al., 2017; Kim et al., 2017; Ku et al., 2017; Kwon et al., 2017; Kedkovid et al., 2018; Klaumann et al., 2018). In Brazil, few studies about the circulation of PCV3 have been published (Tocheto et al., 2017; Saraiva et al., 2019; Rodrigues et al., 2020) and there is lack of information about the circulation and the clinical impact of this virus in Brazilian herds. In order to elucidate the epidemiology and clinical aspects of the infection in this population, the aim of this study was to perform molecular detection of PCV-3 using a nested PCR designed for this purpose and swine serum samples from Southeastern - Brazil.

\section{MATERIAL AND METHODS}

The samples $(n=154)$ were collected in 31 conventional pig farms during the years of 2013, 2014, 2017, and 2018. The pigs were located in 20 cities in the Southeast of Brazil, 15 cities in the State of Rio de Janeiro and 5 cities in the State of Espirito Santo. The distribution of the samples by year and by state is shown in the Table 1 .

Table 1. Distribution of the samples tested by nested PCR for PCV-3 in this study by year and state

\begin{tabular}{lccc} 
State & \multicolumn{2}{c}{$\begin{array}{c}\text { Number of the samples } \\
\text { by state }\end{array}$} & $\begin{array}{c}\text { Total } \\
\text { samples } \\
\text { per year }\end{array}$ \\
\cline { 2 - 3 } & RJ & ES & 51 \\
\hline 2013 & 51 & 0 & 59 \\
2014 & 59 & 0 & 22 \\
2017 & 0 & 22 & 22 \\
2018 & 0 & 22 & 154 \\
TOTAL & 110 & 44 & \\
\hline
\end{tabular}

The pigs included in this study were classified into three categories according to age: 21 pigs in the nursery stage (3-10 weeks), 114 in the growth stage (11-15 weeks) and 19 in the finishing ( $\geq 16$ weeks) stage. Of the 154 animals, 77 were female and 77 were males. The same veterinarian performed the clinical examination prior to blood collection and all data were recorded for further analysis. In addition, animals were separated into four categories according to the clinical signs presented at the time of samples collection as described by Cruz et al. (2016): diarrhea $(n=22)$, respiratory signs (cough, sneeze and secretion) $(\mathrm{n}=45)$, multiple signs (arthritis, cough, and diarrhea) $(\mathrm{n}=16)$, and no clinical signs $(n=71)$.

DNA was extracted from serum samples using a commercial kit (High Pure Viral Nucleic Acid Kit@, Roche, Germany) according manufacturer's instructions. In a preliminary study conducted at the Animal Virology Laboratory, UFF, 10 serum swine samples were used with the previously published PCR protocol to amplify a 648 bp fragment from the capsid protein gene (ORF2) (1339-1987 nucleotide, nt; GenBank access number KY075986) as described by $\mathrm{Ku}$ et al. (2017). In order to increase the PCR limit of detection in swine serum samples, new nested PCR primers (5'- CCATTGAACGGTGGGGTCAT-3'/ 5'TGGACCACAAACACTTGGCT-3') were designed for this study with Prime 3 software (www.prime3software.com), based on the complete PCV-3 sequence KY076027, available from GenBank.

The primers target a 203 bp internal fragment (1442-1645) of the ORF2 gene. The reaction was performed with $11 \mu \mathrm{l}$ of a commercial master mix, 10 pmol of each PCV3-NF and PCV3-NR primers, and $5 \mu \mathrm{l}$ of the amplified PCR product with a final reaction volume of $20 \mu 1$. The thermal cycling conditions were as follows: $94^{\circ} \mathrm{C}$ for $5 \mathrm{~min}$, followed by 35 cycles at $94^{\circ} \mathrm{C}$ for $30 \mathrm{~s}$, $52^{\circ} \mathrm{C}$ for $30 \mathrm{~s}, 72^{\circ} \mathrm{C}$ for $30 \mathrm{~s}$, and $72^{\circ} \mathrm{C}$ for $10 \mathrm{~min}$. The PCR products were separated using a $1.5 \%$ agarose gel (GIBCO-BRL ${ }^{\circledR}$ ), and electrophoresis was carried out in $1 \mathrm{x}$ TAE buffer at $70 \mathrm{~V}$ for $90 \mathrm{~min}$. The images were generated in an image capture system (BioImaging Systems ${ }^{\circledR}$ ) using the Labworks 4.0 program.

To confirm the specificity of the new primers, bidirectional sequencing of two PCR products (RJ018/2014 and ES310/2018) was performed (Myleus Biotechnology, Belo Horizonte, Brazil) using the ABI3130 automated sequencer 
(Applied Biosystems, Foster City, CA) and BigDye v3.1 reagent (Applied Biosystems, Foster City, CA). The Basic Local Alignment Search Tool (BLASTn) software was used to evaluate the similarity of these products to worldwide sequences available in this database.

The Chi-Square test with $5 \%$ probability was used to verify whether there was a significant difference between frequencies of positive and negative animals by production phases, clinical signs, or genders. The Chi-Square test was performed with SPSS18.0 program (IBM Corp, 2009). The study protocol was approved by the Federal Fluminense University Ethics Committee of Animal Research approval (CEUA/UFF number 2491130718).

\section{RESULTS}

All samples $(n=10)$ tested negative for PCV-3 using the PCR protocol. However, based on the nested PCR, PCV-3 was detected in 41 of 154 (26.7\%) swine serum samples. In addition, the virus was detected within $48.4 \%(15 / 31)$ of the pig farms, with incidence rates of $53.3 \%(8 / 15)$ in the cities in Rio de Janeiro State and in $80 \%$ (4/5) of the cities in Espirito Santo State. The distribution of the positive samples by year and state is shown in the Table 2.

Table 2. Total of the positive samples tested by nested PCR for PCV-3 by year and state

\begin{tabular}{cccc}
\hline & \multicolumn{2}{c}{$\begin{array}{c}\text { Total of the positive } \\
\text { samples by state }\end{array}$} & $\begin{array}{c}\text { Total of the } \\
\text { positive } \\
\text { samples per } \\
\text { year }\end{array}$ \\
\cline { 2 - 4 } & RJ & ES & 03 \\
2013 & 03 & 0 & 21 \\
2014 & 21 & 0 & 08 \\
2017 & 0 & 08 & 09 \\
Total & 24 & 09 & 41 \\
\hline
\end{tabular}

Concerning the production phase, the viruses was more frequent in the nursery phase $(7 / 21$; $33.3 \%$ ), but no statistically significant association was observed between PCV-3 and production phases $(\mathrm{P}=0.761)$. Additionally, no statistical association was observed between the PCV-3 detection and symptomatic (enteric, respiratory or multiple signs) or asymptomatic animals $(\mathrm{P}=0.897)$. However, analyzing each group of clinical signs separately, an association was observed between the presence of respiratory signs and detection of PCV-3 $(\mathrm{P}=0.028)$. The genders of the animals had no significant effect on $\mathrm{PCV}-3$ positivity $(\mathrm{P}=0.985)$ (Table 3). Using the BLASTn software, $100 \%$ similarity of the sequenced samples (RJ018/2014 and ES310/2018) was observed with other PCV3 sequences available from GenBank. Sequences generated in this study were deposited in the GenBank (accession numbers: MN974415 and MN974416, respectively).

Table 3. PCV-3 DNA detection according to production phases, clinical signs and genders $(\mathrm{N}=154)$

\begin{tabular}{lll}
\hline \multicolumn{1}{c}{ Characteristics } & \multicolumn{1}{c}{ PCV-3 } & p value \\
& $41 / 154(26.7 \%)$ & \\
\hline Production phase & Pos/tested (\%) & 0.761 \\
Nursery & $7 / 21(33.3 \%)$ & \\
Growing & $28 / 114(24.5 \%)$ & \\
Finishing & $6 / 19(31.5 \%)$ & \\
Clinical signs & Pos/tested (\%) & 0.897 \\
All clinical signs & $21 / 83(25.3 \%)$ & \\
Diarrhea & $0 / 22$ & \\
Respiratory & $16 / 45(35.5 \%)$ & $0.028^{*}$ \\
Multiple & $5 / 16(31.2 \%)$ & \\
No signs & $20 / 71(28.1 \%)$ & \\
Genders & Pos /tested (\%) & 0.985 \\
Female & $19 / 77(24.7 \%)$ & \\
Male & $22 / 77(28.6 \%)$ & \\
\hline * significant at 5\% &
\end{tabular}

\section{DISCUSSION}

Conventional PCR is considered to be most suitable diagnostic technique for PCV-3 and the DNA detection of the virus has been documented by several authors in pigs with and without clinical signs in tissues, serum, oral fluid and semen (Fu et al., 2017; Kim et al., 2017; Franzo et al., 2018; Guo et al., 2019; Rodrigues et al., 2020). The development of techniques with low cost and high sensitivity is extremely important because it allows the monitoring of the circulation of the virus in swine herds, even in asymptomatic animals (Franzo et al., 2018). Nested PCR has these advantages and facilitates diagnosis even in laboratories with lessdeveloped technology.

Initially, a PCR reaction targeting the ORF2 region (viral capsid) designed by Ku et al. (2017) was adopted for PCV-3 diagnosis in different biological swine samples from Rio de Janeiro and Espirito Santo. This approach revealed 
satisfactory results in frozen tissues, but showed negative results in formalin-fixed paraffinembedded (FFPE) tissues (Rodrigues et al., 2020) and serum (this study). In this case, the design of a nested PCR approach based on a small (203 pb) DNA fragment was a strategy to increase PCV-3 genome detection in serum samples.

The lack of viral genome detection in the serum after conventional PCR (Ku et al., 2017) could be explained by low viremia at the time of sample collection or due to the dynamics of PCV-3 infection, especially in asymptomatic or subclinical animals (Stadejek et al., 2017; Zhai et al., 2017). Serum is the sample of choice for this population due to non-invasive collection; serum has also been used for the diagnosis of circovirus at the Animal Virology Laboratory, UFF, since 2013 (Cruz et al., 2016).

Different studies have reported PCV-3 prevalence in diverse clinical samples, ranging from $1.85 \%$ to $65.0 \%$ (Zhai et al., 2017; Wen et al., 2018; Zou et al., 2018; Qi et al. 2019; Saraiva et al., 2019). Studies using serum as a clinical sample have reported prevalence ranging from $28.7 \%$ to $65.0 \%$ (Palinski et al., 2016; Ku et al., 2017; Stadejek et al., 2017). In this study, PCV-3 was detected in $26.7 \%$ of swine serum samples from healthy animals and animals with varied clinical signs, of both genders and of varying production phases. According to Klaumann et al. (2019), there is no specific pattern of PCV-3 infection that can be inferred from its detection frequency.

The PCV-3 frequencies observed in this study in the cities and in the pig farms are in agreement with those previously published (Kwon et al., 2017; Stadejek et al., 2017; Tochetto et al., 2017; Qi et al., 2019; Saraiva et al., 2019). However, it was not possible to associate the presence of the virus with the geographic characteristics of the cities or characteristics of the pig farms due to a lack of information about the epidemic situation in the cities and the management used on the farms (Saraiva et al., 2019; Saporiti et al., 2020). This study confirms the circulation of the PCV-3 for the first time in Rio de Janeiro.
No statistical association was observed between the production phases and PCV-3 detection, suggesting that PCV-3 infection was ubiquitous on pig farms, affecting animals of all ages (Klaumann et al., 2019; Sukmak et al., 2019). Klaumann et al. (2019) for the first time, recently described long-term infection in few domestic pigs; however, there is no evidence to date of persistent PCV-3 infection in this population as has been observed in wild boar (Sus scrofa scrofa) (Klaumann et al., 2018). Comparing PCV-3 infection dynamics with PCV-2, the ubiquitous characteristic of the virus and the possibility of reinfection could also be considered from successive contacts with the virus throughout the stages of production.

No PCV-3-positive animal in this study had diarrhea. Qi et al. (2019) observed conflicting results, but the authors did not claim that the virus was the primary agent of diarrhea, as other agents had not been researched. However, our results suggested that PCV-3 is not the causative agent of diarrhea, as no single virus-positive animal was observed. Although PCV-3 has already been detected in the intestine (Qi et al., 2019), there has been no evidence until now that PCV-3 causes diarrhea as PCV-2 does.

In this study, the presence of PCV-3 was associated with respiratory signs despite association of PCV-3 with the clinical signs remaining controversial. Franzo et al. (2018) was unable to find statistically significant relevance of PCV-3 infection with any clinical condition, while Zhai et al. (2017) reported that a higher viral load of PCV3 was detected in cases of severe respiratory disease or diarrhea than in mild cases. Thus, the relationship between PCV3 infection and clinical symptoms should be investigated further (Kim et al., 2017).

Based on published data, it has not been established whether PCV-3 infection is related to a particular pathological condition or to any specific age (Klaumann et al., 2018). Despite good progress in PCV-3 epidemiology, the circulation status of PCV-3 in pigs with different clinical presentations (especially asymptomatic animals or those with diarrhea) is not well established (Zhai et al., 2017; Zou et al., 2018). 


\section{CONCLUSIONS}

In conclusion, the nested PCR approach designed in this study confirmed the presence of PCV-3 DNA in serum from animals regardless of age, production phase, gender, or presence of clinical signs. Statistical significance was observed only for the relationship between PCV-3 positivity and respiratory signs. Because PCV-3 is a newly discovered virus, and little information is available regarding its epidemiology, these data aid in future epidemiology of PCV-3.

\section{REFERENCES}

CHEN, N.; HUANG, Y.; YE, M. et al. Coinfection status of classical swine fever virus $(\mathrm{CSFV})$, porcine reproductive and respiratory syndrome virus (PRRSV) and porcine circoviruses (PCV2 and PCV3) in eight regions of China from 2016 to 2018. Infect. Genet. Evol., v.68, p.127-135, 2019.

CRUZ, A.C.M.; SILVEIRA, R.L.; BAEZ, C.F. et al. Clinical aspects and weight gain reduction in swine infected with porcine circovirus type 2 and torque teno sus virus in Brazil. Vet. Microbiol., v.195, p.154-157, 2016.

FRANZO, G.; LEGNARDI, M.; HJULSAGER, C.K. et al. Full-genome sequencing of porcine circovirus 3 fields strains from Denmark, Italy and Spain demonstrates a high within-Europe genetic heterogeneity. Transbound. Emerg. Dis., v.65, p.602-606, 2017.

FRANZO, G.; LEGNARDI, M.; TUCCIARONE, C.M. et al. Porcine circovirus type 3: threat to the pig industry? Vet. Rec., v.182, p.83-84, 2018.

FU, X.; FANG, B.; MA, J. et al. Insights into the epidemic characteristics and evolutionary history of the novel porcine circovirus type 3 in southern China. Transbound. Emerg. Dis., v.65, p.296303, 2017.

GUO, Z.; LI, X.; DENG, R. et al. Detection and genetic characteristics of porcine circovírus 3 based on oral fluids from asymptomatic pigs in central China. BMC Vet. Res., v.15, p.1-6, 2019.

IBM SPSS statistics for Windows. Version 18.0. Armonk, NY: IBM Corp., 2009
KEDKOVID, R.; WOONWONG, Y.; ARUNORAT, J. et al. Porcine circovirus type 3 (PCV3) shedding in sow colostrum. Vet. Microbiol., v.220, p.12-17, 2018.

KIM, H.R.; PARK, Y.R.; LIM, D.R. et al. Multiplex real-time polymerase chain reaction for the differential detection of porcine circovirus 2 and 3. J. Virol. Methods, v.250, p.11-16, 2017.

KLAUMANN, F.; FRANZO, G.; SOHRMANN, M. et al. Retrospective detection of Porcine circovirus 3 (PCV-3) in pig serum samples from Spain. Transbound. Emerg. Dis., v.65, p.12901296, 2018.

KLAUMANN, F.; CORREA-FIZ, F.; SIBILA, M. et al. Infection dynamics of porcine circovirus type 3 in longitudinally sampled pigs from four Spanish farms. Vet. Rec., v.184, p.1-7, 2019.

KU, X.; CHEN, F.; LI, P. et al. Identification and genetic characterization of porcine circovirus type 3 in China. Transbound. Emerg. Dis., v.64, p.703-708, 2017.

KWON, T.; YOO, S.J.; PARK, C.K. et al. Prevalence of novel porcine circovirus 3 in Korean pig populations. Vet. Microbiol., v.207, p.178-180, 2017.

PALINSKI, R.; PIÑEYRO, P.; SHANG, P. et al. A novel porcine circovirus distantly related to known circoviruses is associated with porcine dermatitis and nephropathy syndrome and reproductive failure. J. Virol., v.91, p.1-13, 2016.

PHAN, T.G.; GIANNITTI, F.; ROSSOW, S. et al. Detection of a novel circovirus PCV3 in pigs with cardiac and multi-systemic inflammation. Virol. J., v.13, p.1-8, 2016.

QI, S.; SU, M.; GUO, D. et al. Molecular detection and phylogenetic analysis of porcine circovírus type 3 in 21 provinces of China during 2015-2017. Transbound. Emerg. Dis., v.66, p.1004-1015, 2019.

RODRIGUES, I.L.F.; CRUZ, A.C.M.; SOUZA, A.E.; KNACKFUSS, F.B. et al. Retrospective study of procine circovirus 3 (PCV3) in swine tissue from Brazil (1967-2018). Braz. J. Microbiol., 2020. Available in: https://doi.org/10.1007/s42770-020-00281-6. Accessed in: 25 may 2020. 
SAPORITI, V.; CRUZ, T.F.; CORREA-FIZ, F. et al. Similar frequency of Porcine circovírus 3 (PCV-3) detection in serum samples of pigs affected by digestive or respiratory disorders and age-matched clinically healthy pigs. Transbound. Emerg. Dis, v.67, p.199-205, 2020.

SARAIVA, G.L.; VIDIGAL, P.M.P.; ASSAO, V.S. et al. Retrospective detection and genetic characterization of porcine circovirus 3 (PCV3) strains identified between 2006 and 2007 in Brazil. Viruses, v.11, p.201-212, 2019.

STADEJEK, T.; WOZNIAK, A.; MITEK, D. et al. First detection of porcine circovirus type 3 on commercial pig farms in Poland. Transbound. Emerg. Dis., v.64, p.1350-1353, 2017.

SUKMAK, M.; THANANTONG, N.; POOLPERM, P. et al. The retrospective identification and molecular epidemiology of porcine circovirus type 3 (PCV3) in swine in Thailand from 2006 to 2017. Transbound. Emerg. Dis., v.66, p.611-616, 2019.

TOCHETTO, C.; LIMA, D.A.; VARELA, A.P.M. et al. Full-genome sequence of porcine circovirus type 3 recovered from serum of sows with stillbirths in Brazil. Transbound. Emerg. Dis., v.65, p.5-9, 2017.
WEN, S.; SUN, W.; LI, Z. et al. The detection of porcine circovirus 3 in Guangxi, China. Transbound. Emerg. Dis., v.65, p.27-31, 2018.

YAO, J.; QIN, Y.; ZENG, Y. et al. Genetic analysis of porcine circovirus type 2 (PCV2) strains between 2002 and 2016 reveals PCV2 mutant predominating in porcine populations in Guangxi, China. BMC Vet Res, v.15, n.118, p.1$11,2019$.

ZHAI, S.L.; ZHOU, X.; ZHANG, H. et al. Comparative epidemiology of porcine circovirus type 3 in pigs with different clinical presentations. Virol. J., v.14, n.1, p.222-228, 2017.

ZHENG, S.; WU, X.; ZHANG, L. et al. The occurrence of porcine circovirus 3 without clinical infection signs in Shandong Province. Transbound. Emerg. Dis., v.64, n.5, p.13371341, 2017.

ZOU, Y.; ZHANG, N.; ZHANG, J. et al. Molecular detection and sequence analysis of porcine circovirus type 3 in sow sera from farms with prolonged histories of reproductive problems in Hunan, China. Arch. Virol., v.163, n.10, p.2841-2847, 2018. 